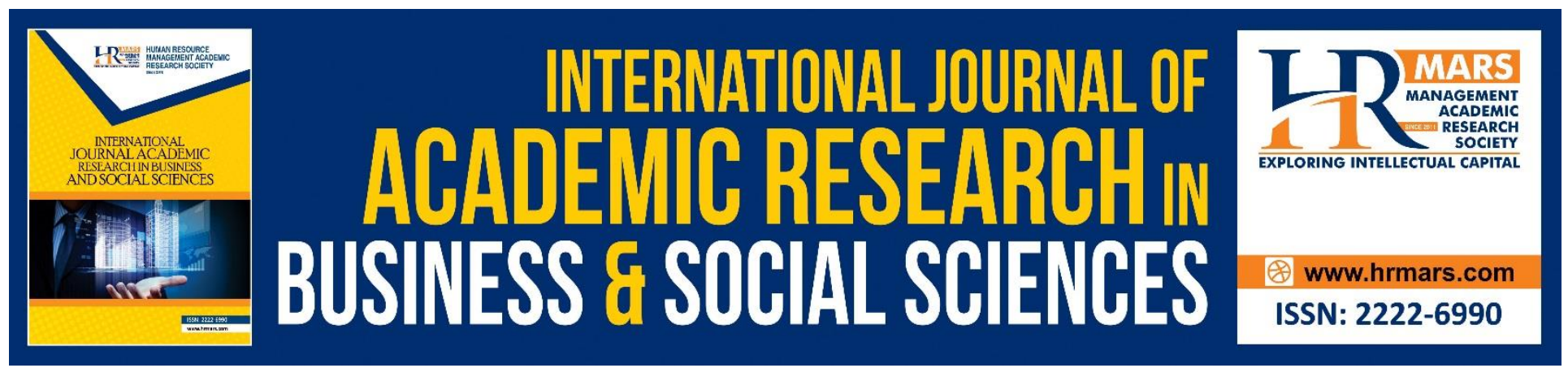

\title{
The Framework of Mobile E-Learning Based On Embedded Technology for Rural Schools
}

\author{
Muhammad Modi Lakulu, Md Zahar Othman, Ismail Yusuf Panessai, \\ Muhammad Rosdi Amat
}

To Link this Article: http://dx.doi.org/10.6007/IJARBSS/v9-i6/5989

DOI: 10.6007/IJARBSS/v9-i6/5989

Received: 13 April 2019, Revised: 19 May 2019, Accepted: 02 June 2019

Published Online: 27 June 2019

In-Text Citation: (Lakulu, Othman, Panessai, \& Amat, 2019)

To Cite this Article:Lakulu, M. M., Othman, M. Z., Panessai, I. Y., \& Amat, M. R. (2019). The Framework of Mobile E-Learning Based On Embedded Technology for Rural Schools. International Journal of Academic Research in Business and Social Sciences, 9(6), 735-743.

Copyright: (C) 2019 The Author(s)

Published by Human Resource Management Academic Research Society (www.hrmars.com)

This article is published under the Creative Commons Attribution (CC BY 4.0) license. Anyone may reproduce, distribute, translate and create derivative works of this article (for both commercial and non-commercial purposes), subject to full attribution to the original publication and authors. The full terms of this license may be seen

at: http://creativecommons.org/licences/by/4.0/legalcode

Vol. 9, No. 6, 2019, Pg. 735 - 743

http://hrmars.com/index.php/pages/detail/IJARBSS

JOURNAL HOMEPAGE

Full Terms \& Conditions of access and use can be found at http://hrmars.com/index.php/pages/detail/publication-ethics 


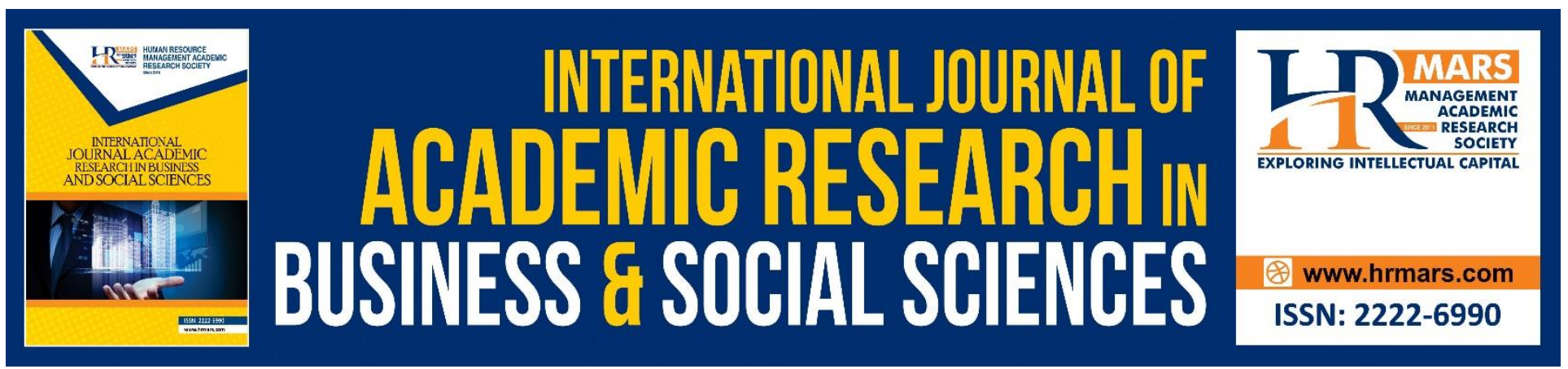

\title{
The Framework of Mobile E-Learning Based On Embedded Technology for Rural Schools
}

\author{
Muhammad Modi Lakulu, Md Zahar Othman, Ismail Yusuf Panessai, \\ Muhammad Rosdi Amat \\ Sultan Idris Education University, Malaysia
}

\begin{abstract}
The problem of using the e-learning system in schools is not about the technology but how to deliver learning contents efficiently via a network. However, the conditions of most existing network infrastructure are not conducive for such a use, which inevitably becomes a huge obstacle to delivering such contents. In particular, such an obstacle is more critical in rural areas where the internet connection is nearly non-existent. Unmitigated, this will adversely affect the government's effort to bridge the digital divide between urban and rural schools. Premised in this context, the research was carried out with the main aim to propose a new framework for cost-effective e-learning based on embedded technology for rural school with affordable cost. To conceptualize such a framework, the researchers analyzed several existing frameworks that are commonly used in most schools. In addition, a survey was carried out to examine the level of adoption of Internet use among teachers. The main finding of the survey showed that the lack of interest among teachers and insufficient infrastructure were two factors that contributed to the poor level of adoption of elearning in such schools. In view of this finding, it is therefore important that the proposed framework can be used to improve the use of e-learning in such schools.
\end{abstract}

Keywords: Educational Technology, E-Learning, Framework Mobile-Learning

\section{Introduction}

Rural areas around the world share several common issues, one of which is that isolated populations of developing nations are facing communication barriers that make the delivery of education materials to such areas challenging and almost impossible. It thus becomes incumbent upon relevant governments to seek ways to help deliver educational contents and materials more efficiently to these areas. The worldwide e-learning market reached $\$ 35.6$ billion (UDS) in 2011 . The five-year compound annual growth rate is estimated at around $7.6 \%$ so revenues should reach some $\$ 51.5$ billion by 2016 . According to recent studies, the highest growth rate is in Asia at $17.3 \%$, followed by Eastern Europe, Africa, and Latin America at 16.9\%, 15.2\% and 14.6\%, respectively (Docebo, 2014). Revenues from the sales of e-learning systems in Asia reached $\$ 5.2$ billion in 2011 and are expected to more than double to $\$ 11.5$ billion by 2016 . Of late, throughout the whole of Asia, government- 
INTERNATIONAL JOURNAL OF ACADEMIC RESEARCH IN BUSINESS AND SOCIAL SCIENCES Vol. 9, No. 6, June, 2019, E-ISSN: 2222-6990 @ 2019 HRMARS

funded projects related to literacy development in rural areas have become a major driver to the introduction of e-learning, which surely will have a positive impact on delivering e-learning contents to school.

The term "digital divide" has traditionally been used to describe discrepancies between nations or socio-economic groups and their corresponding access to technologies (e.g., Norris, 2001) or, more subtly, access to the social and organizational resources needed to use technologies effectively (Warschauer, 2004). Furthermore, e-learning can be used to encourage self-learning and, at the same time, it can cut the cost of delivering training. In terms of place and time, e-learning is more flexible where there is no limitation for learners to engage in learning activities, such as having discussions, sending assignments or sharing documents with other learners (Rantala \& Suoranta, 2008; Fildhouse \& Nicholas, 2008)

In this regard, the implementation strategy of an e-learning system is important to influence student perception (Keller \& Cernerud, 2002). To achieve this, the gap of the digital divide should be ideally eliminated. In Malaysia, such a gap has been spurred by both geographical and financial factors. For example, the digital gap has become so acute between urban and rural areas, given that people living in the former's areas have more flexibility and accessibility to use ICT compared to those living in the latter's areas (Faziharudean, 2005). As such, the digital gap needs to be eradicated by improving ICT use in rural areas to help enhance e-learning (Crus-Jesus et. al., 2016).

Nowadays, e-learning has become an accepted educational paradigm in many higher educational institutions worldwide. An understanding of critical success factors (CSFs) that influence students' positive perception of such a new paradigm is important, as many institutions endeavor to attract and retain students to adopt e-learning courses or programs. The critical factors affecting e-learning acceptance from the students' perspective can be divided into categories, namely technological and institutional support (Masrom et al., 2008).

E-learning based on embedded system is currently a new term used to describe the various uses of information and communications technologies that are used to enhance learning and teaching (AlShboul, 2013). As such, the successful implementation of e-learning based on the embedded system requires an understanding of the issues that promote and support the effective use of the new technology (Bhuasiri et al., 2012; Goi and Ng, 2009). While e-learning provides several benefits that help enhance the quality of education and develop engaging learning environments, many challenges and issues have not been fully addressed that hinder the exploration and utilization of its opportunities (Taha, 2014; Qureshi et al., 2012; Bhuasiri et al., 2012; Mapuva , 2009; Kwofie and Henten , 2011; Alkharang and Ghinea, 2013).

Admittedly, the effective use of embedded technology is one of the main challenges faced by practitioners in the implementation of e-learning in the educational sector. In this respect, embedded technological challenges are defined as the challenges surrounding the issues of familiarity with new technology and technical problems encountered by instructors and other users (Olutola and Olatoye, 2008), such as Internet bandwidth and computer facilities. Clearly, overcoming such issues will require adjustments not only from the organization's side but also from the instructors' and student's sides (Ali and Magalhaes, 2008). A lack of easy access to these technologies as well as a lack of skills necessary to use available computers and communication technology has hindered the instructors' use of e-learning (Wang et al., 2008). 
In fact, (Taruset al., 2015; Khan, 2005) pointed out that the embedded technological challenges of the e-learning framework are concerned with the issues of embedded technology infrastructure in elearning environments. A lack of easy access to necessary computer equipment and other technologies is one of the critical problems in the implementation of e-learning (Wang et al, 2008; Aleman-Meza, 2005). Such challenges also refer to the quality of the connectivity (Kamba, 2009), and the reliability of connection and the bandwidth will affect users' ability to access the full range of the contents needed (Qureshi, et al., 2012). Moreover, the cost of the embedded technologies needed in setting up the e-learning system is considered a limitation to the successful implementation of elearning (Kamba, 2009; Andersson, 2008). According to Ali and Magalhaes (2008), embedded technology is the dominant technology used in the current e-learning system but it is too expensive. For example, the initial cost of buying computers, especially in the early implementation stages, as well as the ongoing costs of upgrading systems, are prohibitively high. Therefore, it is hardly surprising to find this factor has been frequently highlighted in the literature as one of the most significant barriers to the implementation of e-learning. Unfortunately, schools are still away from getting the full benefit and advantages of e-learning because of such embedded technological challenges. Arguably, such fundamental, critical challenges need to be identified and addressed for the successful implementation of e-learning (Yoloye, 2015; Mahmud, and Gope, 2009). As acknowledged, many challenges faced by schools, such as a lack of bandwidth and Internet connectivity, still persist that will have a profound impact on the implementation of e-learning in schools (Taruset al., 2015; Kamba, 2009; Salleh and lahad, 2001; Omidinia et al., 2011).

\section{Methodology}

The research methodology used in the study was based on two methods, namely a survey method and framework formulation method. For the survey method, 97 teachers of the Sek. Men. Keb. Syed Mashor, Batang Kali, Selangor were selected to fill out questionnaires, asking them about their gender, level of education, age, and teaching experience. For the framework formulation method, two steps were involved that the researchers had to perform based on the earlier work of (Lakulu, et al., 2010, Lakulu, Rusli and Zidan 2017, Mohamad and Lakulu 2017). First, existing frameworks were critically analyzed to identify the relevant components. Finally, a new conceptual framework was proposed based on such identified. In fact, the proposed conceptual framework was formulated based on the findings of the survey and the analysis of existing frameworks. Such an approach was vital to be in line with the objectives and limitations of this study.

\section{Framework Formulation}

The framework (see Figure 1) consists of three main components, namely design, learning context, and structural factors. The design has four elements, namely user role and profile, learn on the move (Kim, Lee, \& Rha, 2017), interface design, and media types (Popescu, 2013). The learning context has five elements, namely identity (Parsons, Ryu \& Cranshaw, 2007), learner (Ozdamli \& Cavus, 2011), activity (Leung and Chan, 2003, and Liu, Wang, Liang, Chan and Ko, 003), spatio-temporal and facility (Parsons, Ryu \& Cranshaw, 2007). The structural factor consists of four elements, namely organized contents, outcome and feedback, goals and objective, and training (Woodill, 2012). Figure 1 shows the three main components of the proposed framework. 


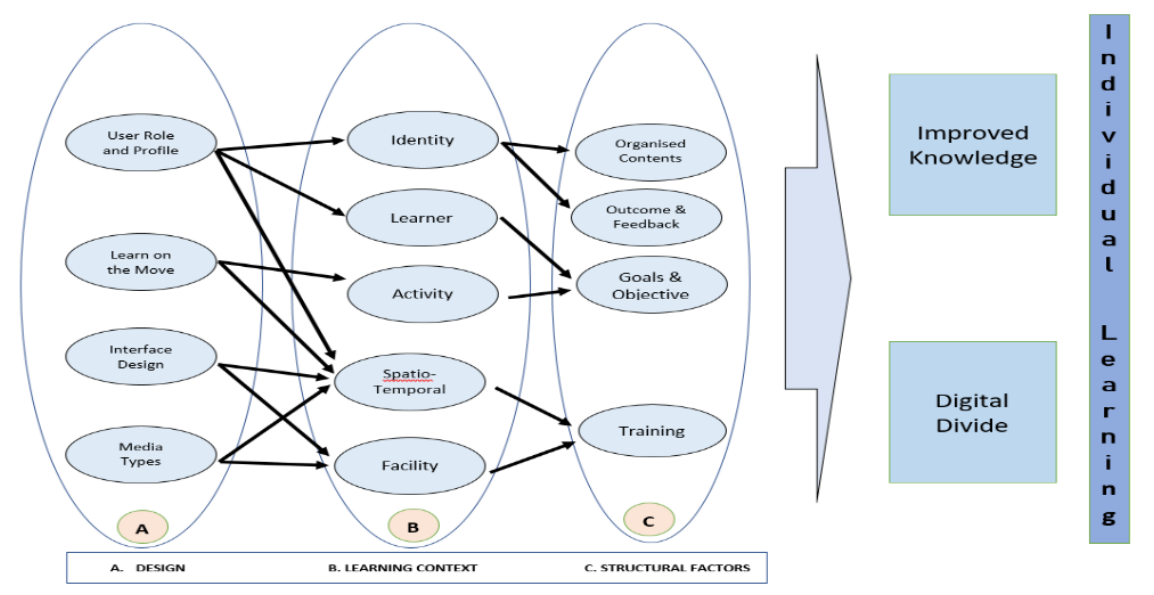

Fig. 1. Mobility Framework

\section{Result and Discussion}

Descriptive analysis showed that 94 respondents comprised 70 female teachers, representing $74.5 \%$ of the total respondents. The remaining 24 were male teachers, representing $25.5 \%$ of the respondents. The analysis showed that 82 respondents (87.2\%) had basic Internet access, while the remaining 12 (12.8\%) did not such access. In terms of age, 16 respondents (17\%) were in the $21-30$ year age group, while 31 respondents (33\%) were in the age range of $31-40$ years. At $45.7 \%(n=43)$, the majority of the respondents was in the age range of $41-50$ years. In contrast, those aged above 51 years were the minority, represented only by $4.3 \%(n=4)$. In terms of teaching experience, 26 of the respondents $(27.7 \%)$ indicated they had been teaching between one and five years, and 11 of the respondents $(11.7 \%)$ had teaching experiences in a range of 6 and 10 years. Meanwhile, 22 of the respondents (23.4\%) reported that their teaching experiences ranged from 11 to 15 years, and the remaining 35 respondents (37.5\%) stated they had more than 16 years of teaching experience.

For educational background, the numbers (percentages) of respondents who reported that they specialized in Computer Science (ICT), Science, Arts (Malay Language), and Islamic or Moral Studies, and Sports Science were 4 (4.3\%), 11 (11.7\%), 19 (20.2\%), 13 (13.8\%), and 4 (4.3\%), respectively. Those specializing in Geography or History, Economics, Mathematics, English Language and others were represented by 8 (8.5\%), 7 (7.4\%), 6 (6.4\%), 9 (9.6\%), and $13(13.8 \%)$ respondents, respectively. In terms of Internet use, 19 respondents (20.1\%) indicated that they used the Internet for 2 hours per week. By contrast, more than half of the respondents (57 or 60\%) indicated that they used the Internet between 2 and 10 hours per week. The remaining 11 respondents $(11.7 \%)$ and $7(7.4 \%)$ respondents reported that they used the Internet between 10 and 20 hours per weeks and more than 20 hours per week, respectively.

In addition, the respondents provided the required feedback to the several specific questions as follows:

a) Are you fully prepared in implementing e-learning in your school?

The majority of the respondents, as represented by 67 respondents (71.2\%), indicated that they were fully prepared to implement such an implementation. Those stated that they were moderately 
prepared were represented by 20 respondent's $(21.3 \%)$. Only a small minority of the respondents, as represented by 7 respondents $(7.4 \%)$, indicated that they were not prepared in the implementation of e-learning in their school.

b) Is your school's existing infrastructure sufficient to support e-learning?

More than half of the respondents indicated that the level of infrastructure to support e-learning in their school was very high, as represented by 54 respondents (57.5\%). In contrast, those stated |that the levels of infrastructure to support e-learning were moderately high and low were equally represented by 20 respondents (21.3\%).

c) Are the hardware and software sufficient to support the implementation of e-learning?

More than half of the respondents indicated that the hardware and software for such an implementation were at a very high level, as represented by 55 c (58.5\%). In contrast, 24 (25.5\%) and $15(16 \%)$ respondents stated that the levels of existing hardware and software for the implementation of e-learning were moderately high and low, respectively.

d) What are the challenges that exist in the implementation of e-learning in your school?

One respondent stated that he was not interested in the implementation of e-learning because he lacked the right exposure to such an approach.

e) What are the factors that influence the use of e-learning in the school?

Two factors were cited to be influential in the implementation of e-learning, made evident by the one respondent who stated that he did not really bother to know more about the latest development in technology.

f) Is teachers' current knowledge of technology sufficient to help them implement e-learning?

The majority of the respondents, as represented by 81 respondents $(86.2 \%)$, indicated that their level of knowledge was very high. In contrast, the numbers (percentages) of those indicating that their level of such knowledge was at a moderate level and low level were $12(12.8 \%)$ and $1(1.1 \%)$, respectively.

g) Do teachers need more training before the implementation of e-learning in school?

Almost two-thirds of the respondents (64 or 68.1\%) stated that they needed moderate training while 26 of the respondents $(27.7 \%)$ indicated that they required intense training. On the other hand, a small minority of the respondents (4 or $4.3 \%$ ) indicated that they only needed basic training.

\section{Conclusion}

Overall, the findings of this study strongly suggest that the implementation of e-learning in such schools will be very challenging due to a host of factors. As revealed, the current state of affairs in such schools is fraught with many problems, such as poor working condition, a lack of interest among teachers, and insufficient infrastructure. Most notably, poor connectivity to the Internet is the main problem that may curtail efforts in implementing e-learning in most schools. As such, the proposed implementation framework of e-learning based on embedded technology can be used to help mitigate such problems, which over the long run can help narrow the digital gap between urban and rural school children. Basically the proposed framework is to solve the poor connectivity of the Internet especially in the rural area, whereby we bring the Internet into the class. Thus, the teaching and learning activities using e-learning is not rely on the Internet anymore, which can help students from rural area to learn more effectively using e-learning. 
INTERNATIONAL JOURNAL OF ACADEMIC RESEARCH IN BUSINESS AND SOCIAL SCIENCES

Vol. 9, No. 6, June, 2019, E-ISSN: 2222-6990 (C) 2019 HRMARS

\section{Acknowledgement}

This research is fully supported by GPU grant, 2017-0186-109-01. The authors fully acknowledged Universiti Pendidikan Sultan Idris for the approved fund which makes this important research viable and effective.

\section{Corresponding Author}

Muhammad Modi Lakulu

Sultan Idris Education University, MALAYSIA

Email: modi@fskik.upsi.edu.my

\section{References}

Aleman-Meza B., Burns P., Eavenson M., Palaniswami D., Sheth A. (2005) An Ontological Approach to the Document Access Problem of Insider Threat. In: Kantor P. et al. (eds) Intelligence and Security Informatics (ISI 2005), (Atlanta,Georgia, USA, 2005).

Alkharang, M. M., \& Ghinea, G. (2013). E-learning in Secondary Educational Institutions in Kuwait: Experiences and Challenges. International Journal of Advanced Computer Science and Applications, 4(4), 1-6.

Ali, G. E., \& Magalhaes, R. ( 2008). Barriers to implementing e-learning: a Kuwaiti case study. International journal of training and development, 12(1), 36-53.

Al-Shboul, M. (2013). The level of e-Learning integration at The University of Jordan: Challenges and opportunities. International Education Studies, 6(4), 93-113.

Andersson, A. (2008). Seven major challenges for e-learning in developing countries: Case study eBIT, Sri Lanka. International Journal of Education and Development using ICT, 4(3), 45-62.

Bhuasiri, W., Xaymoungkhoun, O., Zo, H., Rho, J. J., \& Ciganek, A.P. (2012). Critical success factors for e-learning in developing countries: A comparative analysis between ICT experts and faculty. Computers \& Education, 58(2),843- 855.

Clark, R. C., \& Mayer, R. E. (2003). e-Learning and the Science of Instruction. San Francisco: Pfeiffer. [8] Cruz-Jesus, F., Vicentre, M.R., Cacao. F., \& Oliveira, T. (2016). The education-related digital divide: An analysis for the EU-28. Computers in Human Behavior, 56, 72-82.

Docebo (2014). E-Learning Market Trends \& Forecast 2014-2016. Retrieved from http://www.docebo.com

Fieldhouse, M., \& Nicholas, D. (2008). Digital Literacy as Information Savvy: The Road to Information Literacy. In A Digital Literacies: Concepts, Policies and Practices (Pp 47-72).New York,NY: Peter Lang.

Goi, C. L. \& Ng, P. Y. (2009). E-learning in Malaysia: Success factors in implementing e-learning program. International Journal of Teaching and Learning in Higher Education, 20(2), $237-$ 246.

Kamba, M. (2009). Problems, challenges and benefits of implementing elearning in Nigerian schools: An empirical study. International Journal of Emerging Technologies in Learning (iJET), 4(1), 66-69.

Khan, B. (2005). Learning features in an open, flexible and distributed environment. AACE Journal, 13(2),137-153. 
INTERNATIONAL JOURNAL OF ACADEMIC RESEARCH IN BUSINESS AND SOCIAL SCIENCES

Vol. 9, No. 6, June, 2019, E-ISSN: 2222-6990 @ 2019 HRMARS

Kwofie, B., \& Henten, A. (2011). The advantages and challenges of e-learning implementation: The story of a developing nation. Paper presented at WCES-2011 3rd World Conference on Education Sciences, Bahcesehir University, Istabul, Turkey.

Keller, C., \& Cernerud, L. (2002). Students' Perception of E-learning in University Education. Journal of Educational Media, 27(1-2), 55-67.

Lakulu, M., Abdullah, R., Selamat, M, H., Ibrahim, H., Nor, M. Z. M. (2012). A Framework of Collaborative Knowledge Management System in Open Source Software Development Environment. Computer and Information Science. 3(1), 81-90.

Lakulu, M. M., Abdullah, R, Zidan, A. A. (2017). An Evaluation of A KMS Framework For An Open Source Software Development In A Collaborative Environment. Science International, 29(2), 137-141.

Mahmud, K. \& Gope, K. (2009). Challenges of implementing e-learning for secondary education in least developed countries: a case study on Bangladesh. Paper presented 2009 International Conference on Information and Multimedia Technology, Jeju Island.

Mapuva, J. (2009). Confronting challenges to e-learning in Secondary education institutions. International Journal of Education and Development Using ICT, 5(3),101-114.

Masrom, M., Zainon, O., Rahiman, R. (2008). Exploring the Key Factors in Institutional e-Learning Implementation. In e-learning Issues in Malaysia Higher Education, Mohd Fuad Mohd Salleh (pp. 72-85). Skudai: UTM.

Putih, M. (2008). E-learning concepts and Literature Review. In e-learning Issues in Malaysia Higher Education, Mohd Fuad Mohd Salleh (pp. 72-85). Skudai: UTM.

Norris, P. (2001). Digital divide: Civic engagement information poverty, and the Internet Worldwide. Cambridge, New York: Cambridge University Press.

Omidinia, S., Masrom, M., \& Selamat, H. (2011). Review of e-learning and ICT infrastructure in developing countries (case study of Iran). American Journal of Economics and Business Administration, 3(1), 120-125.

Qureshi, I. A., Ilyas, K., Yasmin, R., \& Whitty, M. (2012). Challenges of implementing e-learning in a Pakistani Primary School. Knowledge Management \& E-Learning. An International Journal (KM\&EL), 4(3), 310-324.

Rantala, L., \& Suoranta, J. (2008). Digital Literacy Policies in the EU-Inclusive Partnership as the Final Stage of Govermentality. In A Digital Literacies: Concepts, Policies and Practices (pp 91-117). New York,NY: Peter Lang.

Rosenberg, M. J. (2001). E-Learning: Strategies for Delivering Knowledge in the Digital Age. New York: McGraw-Hill.

Salleh, M. \& Lahad, N. A. (2011). Challenges of e-learning in Nigerian schools education based on the experience of developed countries. International Journal of Managing Information Technology, 3(2),39-48.

Selwyn, N., \& Gorard, S. (2003). Reality Bytes: Examining the Rhetoric of Widening Educational Participation via ICT. British Journal of Educational Technology, 34(2), 169-181.

Taha, M. (2014). Investigating the success of E-learning in secondary schools: The case of the Kingdom of Bahrain (Doctoral dissertation). Retrieved from http://bura.brunel.ac.uk/handle/2438/9237 
Tarus, J. K., Gichoya, D., \& Muumbo, A. (2015). Challenges of implementing e-learning in Kenya: A case of Kenyan public schools. The International Review of Research in Open and Distributed Learning,16(1), 120-141.

https://dspace.wul.waseda.ac.jp/dspace/bitstream/2065/2949/3/Honbun-3972.pdf

Mahmud, K. \& Gope, K. (2009). Challenges of implementing e-learning for secondary education in least developed countries: a case study on Bangladesh. Paper presented 2009 International Conference on Information and Multimedia Technology, Jeju Island.

Wang, S. C., Cowie, B., \& Jones, A. (2008). Challenges of e-learning for school instructors in Taiwan. Paper presented in The 16th International Conference on Computers in Education (ICCE 2008). Taipei, Taiwan.

Warschauer, M. (2004). Technology and social inclusion: Rethinking the digital divide. Cambridge, MA: MIT Press. 